\title{
Digital Image Correlation Measuring of Strain and Stress Distribution on Mixed Adhesive Joints Bonded by Honeymoon Adhesion Using Two Types of Second-Generation Acrylic Adhesives of Two Components
}

\author{
Shota KAWASAKI*, Yu SEKIGUCHI**, Gosuke NAKAJIMA***, \\ Kosuke HARAGA ****, Chiaki SATO**
}

\begin{abstract}
For stress relief in the adhesive layer, various methods have been proposed, including the use of scarf joints. However, these techniques are highly dependent on the adherend thickness and are thus of limited use. The stress concentration of the joints can be relaxed by using mixed adhesive joints (MAJs), which employ a brittle adhesive in the middle portion of the overlap and a ductile adhesive at the bondline ends. In a previous paper, we proposed a manufacturing method of adhesive joints that have a variable modulus adhesive layer. When using the proposed method, adhesive flow has a significant effect on the adhesive layer property distribution. Considering adhesive flow using finite element analysis or numerical analysis is difficult. Therefore, an experimental evaluation is necessary to elucidate the actual behaviors of these joint types.

The principal aim of this study was to investigate the relationship between applied patterns of brittle and flexible adhesives and the stress distributions of those adhesive layers. Accordingly, stress distributions of single lap joints were evaluated by a tensile test using a digital image correlation (DIC) method. Based on the DIC results, MAJs contributed to the relaxation of the adhesive layer stress concentration. According to the results of the adherend strain distribution, the longer was the soft type of adhesive, the wider was the stress concentration area.
\end{abstract}

Key words: Digital image correlation method, Mixed adhesive joint, Strain and stress distribution, Honeymoon adhesion, Second-generation acrylic adhesives

\section{Introduction}

Adhesive joints have a greater effect on stress relaxation than mechanical fixing methods, such as bolt and rivet fastening ${ }^{1 \sim 3)}$. However, adhesively bonded joints typically

* Department of Mechano-Micro Engineering, Tokyo Institute of Technology, Yokohama, 226-8503, Japan

** Institute of Innovative Research, Tokyo Institute of Technology, Yokohama, 226-8503, Japan

*** Electronic Materials Research Department, Shibukawa Plant, Denka Company Limited, Shibukawa-city, Gunma, 377-8520, Japan

****HARAGA Adhesion Technology Consulting Co., Ltd., Ashiya, Hyogo, 659-0042, Japan

(Received : March 3, 2017) introduce stress concentrations at both ends of the adhesive layer, which results in lower-strength bonds. Therefore, enabling a uniform stress distribution in the joint can effectively increase the joint strength. To obtain a uniform stress distribution in adhesive layers, various methods have been proposed, including the use of scarf joints and stepped joints ${ }^{4)}$. In these methods, the stiffness of the adherend is reduced at the joint ends so that the stress smoothly passes through the adhesive layers. However, these techniques are highly dependent on the thickness of the adherend and are thus limited in use.

Another method to achieve a smooth stress distribution in an adhesive layer is the application of different adhesives within a joint. For example, a joint in which a 
rigid and brittle adhesive is placed at the overlap center, and in which a flexible adhesive is placed at the ends, exhibits a lower stress concentration than other joints that are created using a single adhesive. This method, which produces mixed adhesive joints (MAJs), has been suggested by Raphael ${ }^{5)}$ and studied by other researchers. MAJs have become a more complicated manufacturing method than the approach of using a single adhesive. For such an adhesive joint, a manufacturing method that changes the mixing ratio of the adhesive layer was proposed. Breto and Chiminelli presented an application method that changes the adhesive property in the bondline. The method employs a special applicator, whereby the two different epoxy adhesives of the two components can be mixed ${ }^{6)}$. However, two-part epoxy adhesives are likely to produce hardening failures. Therefore, controlling the mixing ratio is difficult.

In a previous work, we proposed a manufacturing method using two types of second-generation acrylic adhesives (SGAs) of two components ${ }^{7)}$. SGA can be cured at a wide range of mixing ratios. Several methods for varying the adhesive property along the overlap were produced. However, an evaluation method of those types of joint behaviors has not yet been established. In the case of adhesive joints that employ a single adhesive, stress distributions in the adhesive and adherend are important for predicting the adhesive joint strength. Ordinary investigation methods of stress distribution include respective numerical analysis and finite element methods. Volkersen introduced a numerical analysis method of the stress distribution of single lap joints ${ }^{8)}$, and many researchers have advanced study in this area over many years. They revealed that the maximum stress concentration exists near the bondline ends. Furthermore, some researchers examined the relationship between the joint strength and stress distribution of the adhesive joints $^{9,10)}$.

In the cases of MAJs, several published studies have focused on stress distribution using numerical or finite element analyses. Pires et al. ${ }^{11)}$ and Fitton and Broughton ${ }^{12)}$ performed several experiments and finite element analyses on those joints. Their results suggested that this method can effectively improve the strength of single lap joints. However, it is difficult to predict the strength of MAJ using only analytical methods. This is because two key differences exist between the joints of a single adhesive and MAJ, as outlined below.
(1) The boundary of the two different adhesive-layer types is heterogeneous.

(2) The point where the breaking begins is unpredictable because MAJs have multiple stress concentration points.

From those different points, using analytical investigation alone is not adequate for prediction of the stress distribution and joint strength. An experimental evaluation is important to elucidate the actual behaviors of these joint types. The strain distribution can be evaluated by using an optical measuring method. This technique has advantages, such as high sensitivity, noncontact, and full-field measurement. In terms of optical measurement, various approaches include the photoelasticity measuring method ${ }^{13)}$, moiré interferometry method ${ }^{14 \sim 16)}$, and the digital image correlation method (DIC) ${ }^{17,18)}$. The moiré interferometry method produces a highly accurate measurement. However, this method can be affected by disturbances, such as vibration. Therefore, non-interferometric techniques, such as DIC, have been used in research on adhesive joints. The digital image correlation method evaluates the displacement and strain on an object by using the surface pattern. Furthermore, it is robust to vibration and does not require a complicated optical setup.

Haghani et al. investigated the strain distribution in adhesive joints with untapered and normally tapered adherends using DIC ${ }^{19)}$. M. Kashfuddoja and M. Ramji studied the critical strain field in the thin adhesive layer using DIC. Their results were compared with finite element analysis results ${ }^{20)}$. They concluded that DIC can accurately analyze the strain field of adhesive joint specimens.

In the present study, the effects on the stress distribution of applying on adhesive layer patterns of brittle and flexible adhesive layer lengths were investigated. Mixed adhesive joints of each applied pattern were manufactured by varying mixing ratios of second-generation acrylic adhesives (SGAs). The MAJ specimens were evaluated by a tensile test. Strain distributions of these joint types were investigated by using DIC. To analyze the stress distribution, a pure tensile and a pure shear test were conducted, and the stress-strain curves were used for calculating the stress distribution from the strain distribution. Furthermore, the adherend strain distribution was investigated to elucidate the state of the stress distribution on the adherend, which serves as a reference for understanding the adhesive layer stress field. In addition, the adherend strain distribution is a reference for predicting adherend failure. 


\section{Experimental work}

\subsection{Adhesive property}

In this study, two types of SGA-one rigid and brittle; the other flexible-were used. The rigid and brittle adhesive was G-672-15P (Denka Company Limited, Tokyo, Japan), and the flexible one was LDC-141 (Denka Company Limited, Tokyo, Japan). The adhesive characteristics of the mixture of these SGAs were reported by Kawasaki et al. ${ }^{10)}$. Here, the two mixing ratios of the two SGA were used for manufacturing MAJs. One was only brittle SGA; this mixing ratio adhesive is called the "hard-type adhesive." The "softtype adhesive" mixing ratio, on the other hand, had a brittle to flexible mixing ratio of $1: 1$. If only flexible adhesive is used for the end of the adhesive layer, the stress of the ends of the adhesive layer is too low. To achieve uniform stress distribution, Young's modulus of a 1:1 mixing ratio is suitable.

\subsection{Specimen}

\subsubsection{Pure tensile and pure shear tests}

To obtain pure tensile stress-strain curves with respect to each mixing ratio, dumbbell-shaped specimens were pulled by a tensile machine. The displacement rate was set to $1 \mathrm{~mm} / \mathrm{min}$. The characteristics of each dumbbell-shaped tensile specimen for each mixing ratio were reported by Kawasaki et al. ${ }^{10)}$. To obtain pure shear stress-strain curves with respect to each mixing ratio, the cylindrical butt joint specimen was used. The specimen is shown in Fig. 1. Murakami et al. described the mechanism of a cylindrical butt joint specimen and the working principle of a hydraulic testing machine ${ }^{21)}$. The rotational speed of this machine in the test was set to a quasi-static condition $\left(1.745 \times 10^{-4} \mathrm{rad} / \mathrm{sec}\right)$.

\subsubsection{Specimen geometry of single lap joints}

The configuration and dimension of the single lap joints are shown in Fig. 2. The overlap length of all specimens

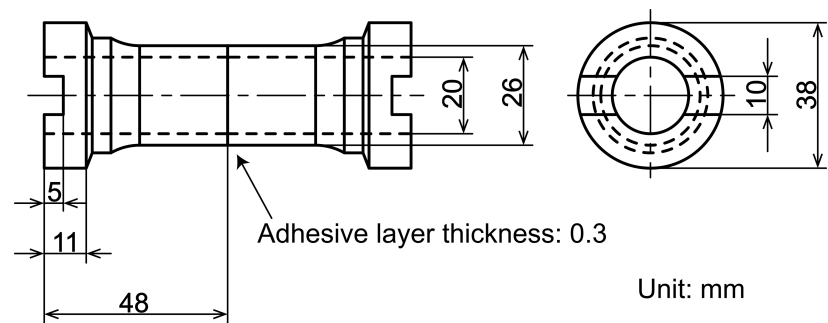

Fig. 1 Dimensions of the cylindrical butt joint for the pure shear test

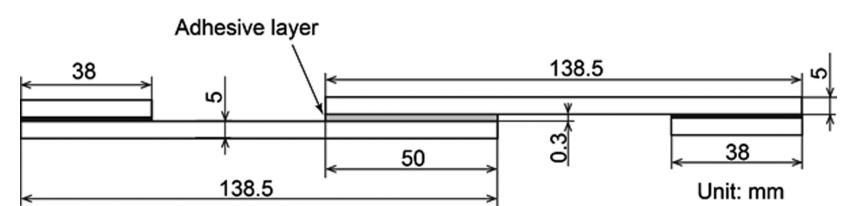

Fig. 2 Dimensions of the single lap joint

was $50 \mathrm{~mm}$. The adhesive-layer thickness was set to $0.3 \mathrm{~mm}$ by dispersing glass beads of $300 \mu \mathrm{m}$ in diameter over the adhesion area. Aluminum alloy (A7075P-T651) was used as the adherend, which had a thickness of $5 \mathrm{~mm}$. The mixing ratio of the SGAs was varied to control the mechanical properties of the adhesive layer. Meanwhile, the applied patterns of the adhesive layer are shown in Fig. 3. Before adhesive application to the adherend, grit blasting was used as a pre-treatment of the adherend surface. After grit

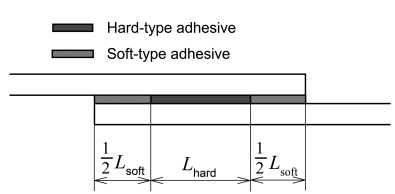

$$
\begin{aligned}
& \text { Specimen name } \\
& \frac{1}{2} L_{\text {soft }}-L_{\text {hard }}-\frac{1}{2} L_{\text {soft }} \text { (Unit: } \mathrm{mm} \text { ) }
\end{aligned}
$$

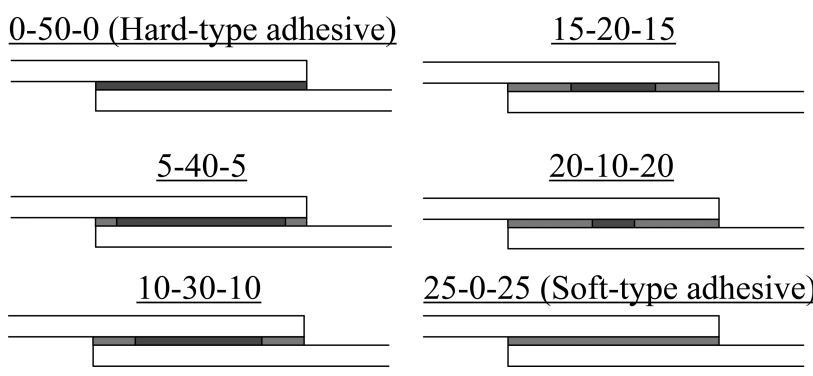

Fig. 3 Applied pattern of each specimen

(a)

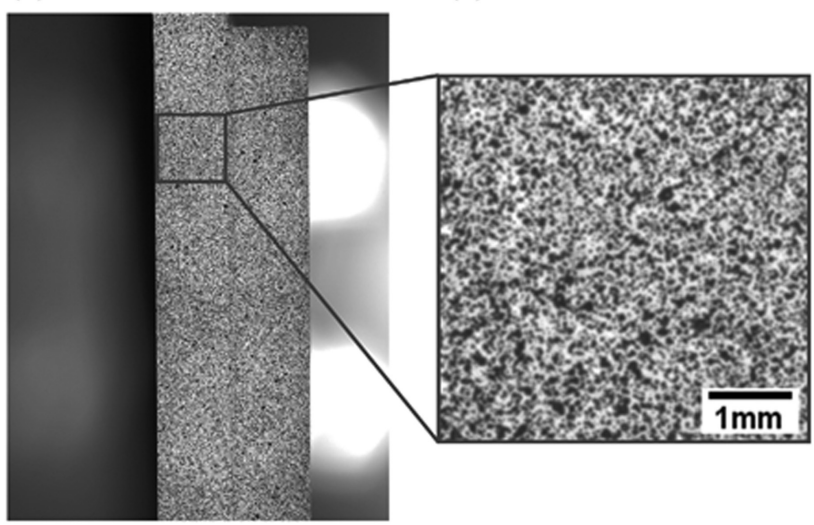

Fig. 4 (a) Upper half of the specimen; (b) enlarged view of the speckle pattern (captured by CCD camera) 
blasting, the adherend surface was degreased with acetone. The specimen surface was covered with a speckle pattern for DIC analysis. Specifically, painted speckle patterns with a white background and black speckles were applied as shown in Fig. 4(a). An enlarged view of the speckle pattern is shown in Fig. 4(b).

\subsection{Specimen manufacture}

Application of the method used in this study was reported in Kawasaki et al. ${ }^{10)}$. This method can apply a mixture of two adhesives to adherends with various mixing ratios, which can create a modulus distribution in the adhesive layer. In this study, MAJs were manufactured by the same method. The application device used in the experiments consisted of two parts: one was a dispenser for two-part adhesives with a static mixer; the other was a multi-axis robot. Each adhesive agent A was separately poured into two different syringes and then placed in a plunger-type dispenser (Measuring Master MPP-1, Musashi Engineering Co., Ltd., Japan). The dispenser was an ordinary machine for two-component-type adhesives and is applicable to various mixing ratios. $\mathrm{B}$ agents were mixed and applied to an adherend with the same procedure as that for A agents. A mixture of A agents was applied to the surface of an adherend, and a mixture of B agents was applied to that of the other adherend at various mixing ratios. Then, one of the adherends was placed on the other to form a joint. After both agents were in contact, the adherends were bonded by honeymoon adhesion, as shown in Fig. 5. When each adhesive layer overlapped, the adhesive mixture flowed from the overlap layer. To prevent the outflowing along the overlap direction, the edges of the adhesive layer in the single lap joints were blocked by silicone blocks, as shown in Fig. 6. The specimens were cured at room temperature for $24 \mathrm{~h}$ and post-cured at $60^{\circ} \mathrm{C}$ for $24 \mathrm{~h}$.

\subsection{Experimental setup of digital image correlation method and testing process}

Tensile tests of single lap joints were performed using a servo-hydraulic cycle test machine (Instron 8802, Illinois Tool Works Inc., USA) with a capacity of $100 \mathrm{kN}$. The experimental setup is shown in Fig. 7. The tests were performed at room temperature (i.e., $25 \pm 3^{\circ} \mathrm{C}$ ). For DIC analysis, the specimen images before the load examination and during the test were captured. A single charge-coupled device (CCD) camera (DMK51BU02, ImageSource, Inc., Washington, USA) was used for capturing the digital images.

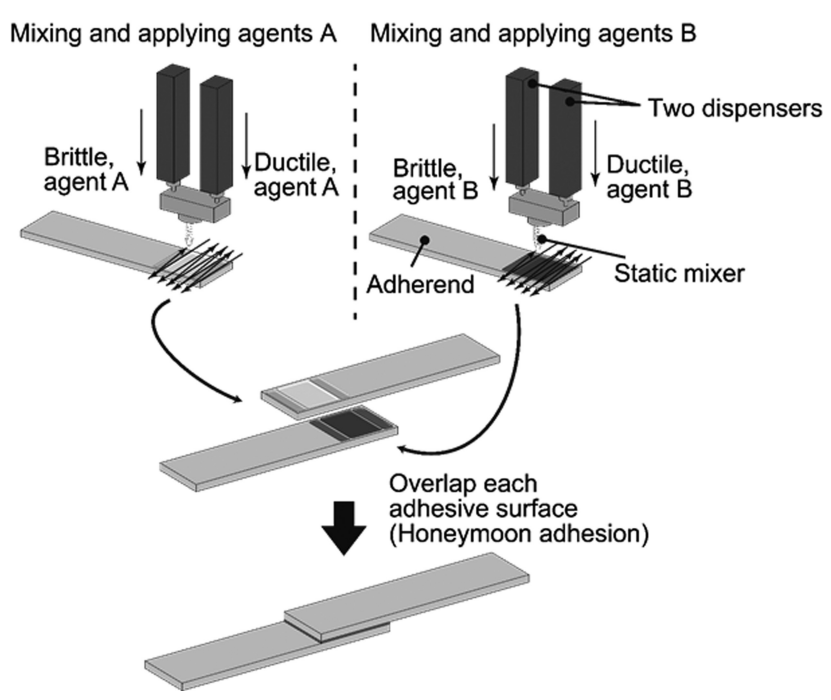

Fig. 5 Manufacturing process of the mixed adhesive joints using honeymoon adhesion

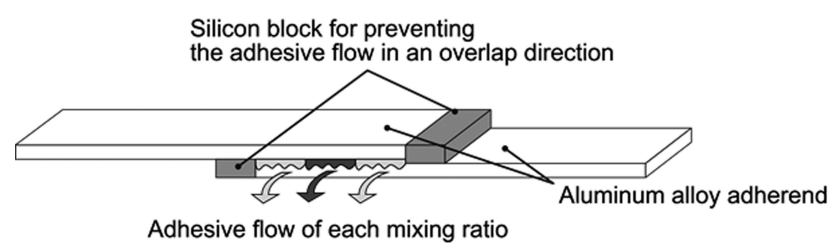

Fig. 6 Silicone block for preventing the adhesive flow in an overlap direction

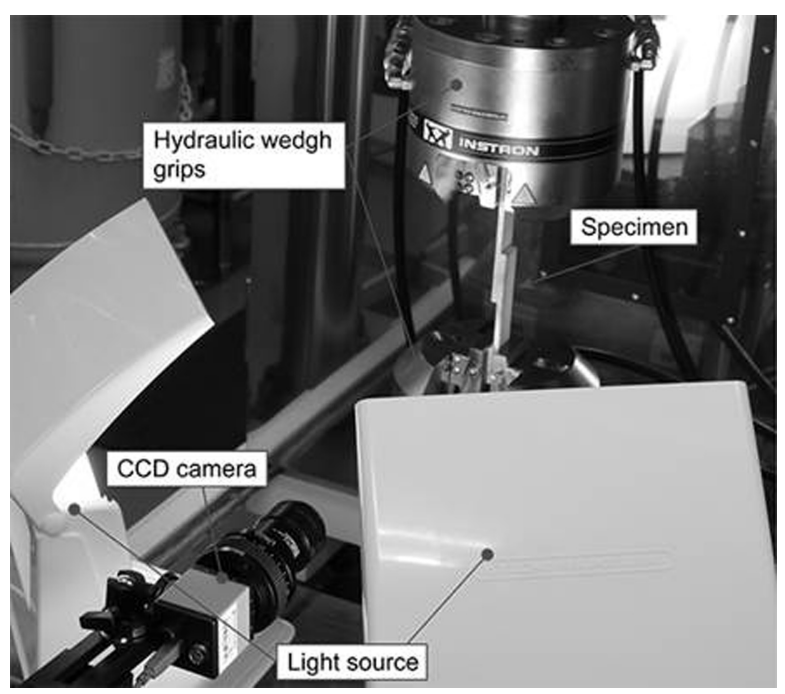

Fig. 7 Experimental setup of the digital image correlation

Fig. 8 shows the measuring area of the adherends and the measuring line along the adhesive layer. The upper-half of the image is the area measured by DIC.

The speckle pattern on the specimen was recorded during the load sequence until the specimen broke down. The photographing time interval was one second. The displacement rate for the tensile tests was set to $0.2 \mathrm{~mm} /$ min. The pixel dimension on each digital image was 


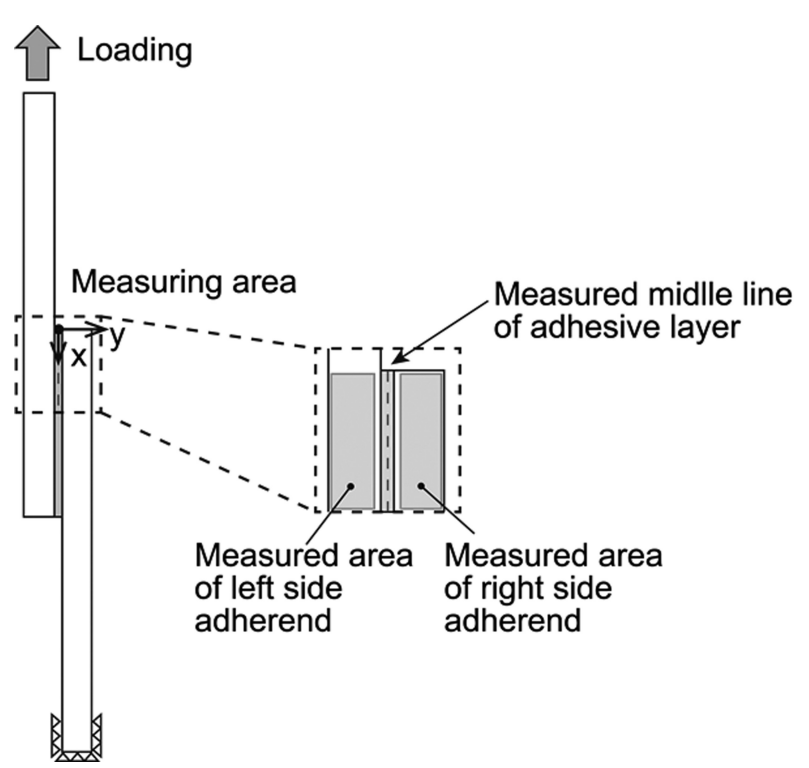

Fig. 8 Schematic diagram of the measured area of the specimen

approximately 50 pixels/mm. The open source MATLAB ${ }^{\circledR}$. based two-dimensional DIC software, Ncorr ${ }^{22}$, which was developed at the Georgia Institute of Technology, USA, was used to measure the strain distribution. To provide distinct strain results, the applied force was set at 15,000 N. The load was set to $15,000 \mathrm{~N}$ because, if the tensile force was low, the noise level of the DIC analysis would have become relatively stronger.

\subsection{Relative equations of strain distribution to stress distribution}

The stress distribution was calculated using the strain distribution. To calculate the stress from the strain in the plastic region, the secant modulus was used. The secant modulus is the slope of the line connecting the origin and a point on the stress-strain curves. Fig. 9 shows a line joining the origin and a point on the curve for calculating the secant modulus. Secant shear modulus $G_{s}$ was calculated from the pure shear stress-strain curve. Secant tensile modulus

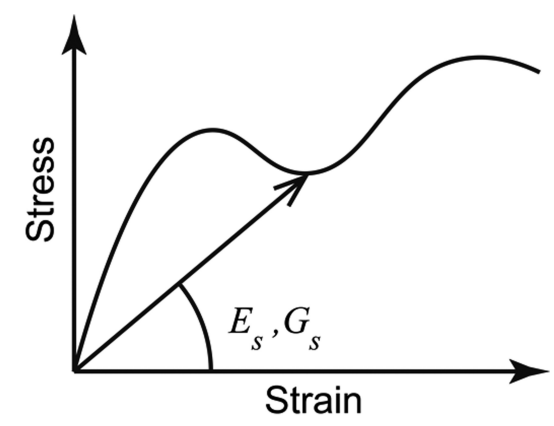

Fig. 9 Slope of the line connecting the origin and a point on a stress-strain curve
$E_{s}$ was also calculated from the pure tensile stress-strain curve. A curve fitting method was utilized to determine the secant moduli. To calculate the stress distribution in the adhesive layer, the adhesive mixing ratio in each location was predicted from the applied position and mixing ratio at the given time. The strains obtained using DIC were used to compute the adhesive peel and shear stresses assuming a plane strain condition. The relative expressions of stress and strain are shown in Eqs. 1,2,3 and 4.

$$
\begin{aligned}
\tau_{x y} & =2 G_{s} \times \varepsilon_{x y} \\
\sigma_{x x} & =\frac{v E_{s}}{(1+v)(1-2 v)}\left(\varepsilon_{x x}+\varepsilon_{y y}\right)+\frac{E_{s}}{1+v} \varepsilon_{x x} \\
\sigma_{y y} & =\frac{v E_{s}}{(1+v)(1-2 v)}\left(\varepsilon_{x x}+\varepsilon_{y y}\right)+\frac{E_{s}}{1+v} \varepsilon_{y y}
\end{aligned}
$$

$$
\sigma_{z z}=\frac{v E_{s}}{(1+v)(1-2 v)}\left(\varepsilon_{x x}+\varepsilon_{y y}\right)
$$

where $\tau_{x y}$ denotes the shear stress, $\sigma_{x x}$ is the normal stress in the x-direction, $\sigma_{y y}$ is the peel stress, $\sigma_{z z}$ is the normal stress in the z-direction, and $G_{s}$ represents the secant shear modulus. In addition, $E_{s}$ denotes the secant tensile modulus, $\varepsilon_{x y}$ is the shear strain, $\varepsilon_{x x}$ represents the normal strain in the x-direction, and $\varepsilon_{y y}$ is the peel strain. While the Poisson's ratio $v=0.38$ was used throughout. These stress values were used for calculating the von Mises equivalent stress. The von Mises equivalent stress was calculated using Eq. 5.

$$
\begin{gathered}
\sigma_{V M}=\sqrt{\frac{1}{2}\left\{\left(\sigma_{x x}-\sigma_{y y}\right)^{2}+\left(\sigma_{y y}-\sigma_{z z}\right)^{2}\right.} \\
\left.+\left(\sigma_{z z}-\sigma_{x x}\right)^{2}+6 \tau_{x y}^{2}\right\}
\end{gathered}
$$

where $\sigma_{V M}$ represents the von Mises equivalent stress.

\section{Result and discussion}

\subsection{Pure tensile test and pure shear test}

Fig. 10 shows the pure tensile stress-strain curves, while Fig. 11 shows the pure shear stress-strain curves. Each curve and secant moduli were acquired from curve fitting. The figures show that each adhesive type has a wide plastic deformation zone. Moreover, in the plastic deformation area, stress does not rise and the secant modulus decreases. 


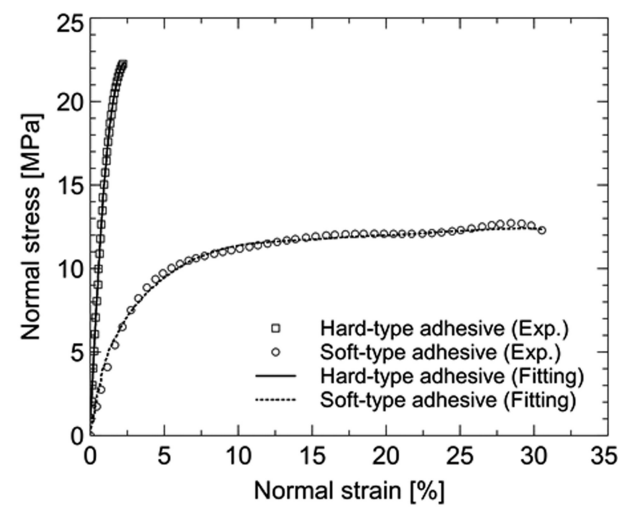

Fig. 10 Pure tensile stress-strain curves and the fitting curves

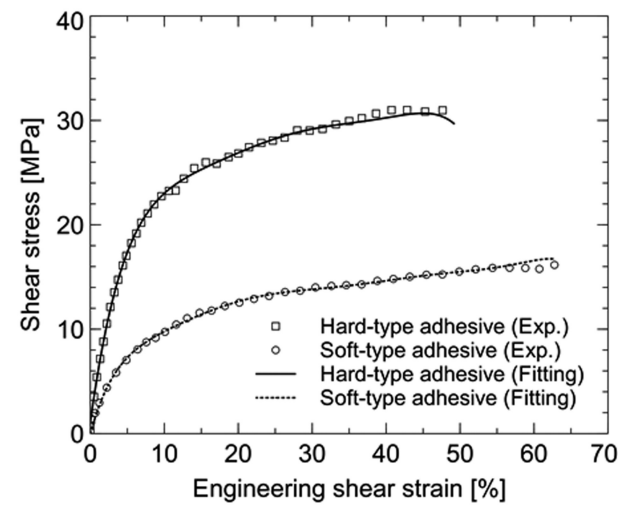

Fig. 11 Pure shear stress-strain curves and the fitting curves

\subsection{Force displacement curves of single lap joints}

Fig. 12 shows the force displacement curves of each specimen. Specimen 25-0-25 (a soft-type adhesive, independently tested) was broken at the low force. For the other specimens, the lap joint strengths were almost the same. From these results, the high joint strengths were maintained, even if the hard-type adhesive was applied only on the small area.

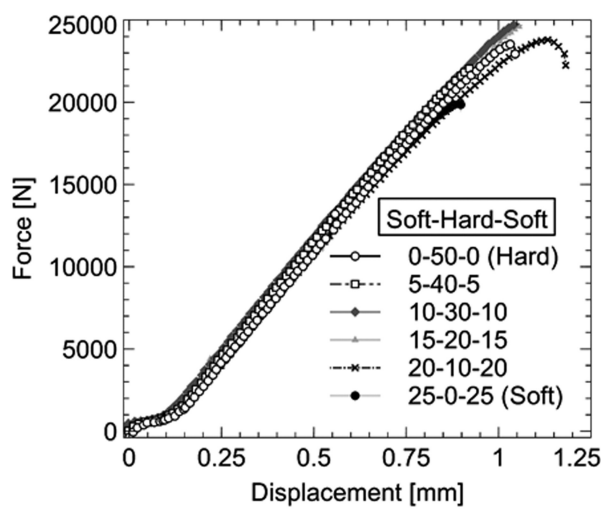

Fig. 12 Force-displacement curves of each Single lap joints

\subsection{Strain distribution}

\subsubsection{Strain distribution of the adhesive layer}

Fig. 13 shows the shear strain distribution on the adhesive layer with the applied 15,000-N load. Fig. 14 shows the peel strain distribution on the adhesive layer with the applied 15,000-N load. From the results, for the specimen 0-50-0 (a hard-type joint, independently tested), the maximum shear and peel strain is the lowest in all specimens. When the MAJ specimens were tested, the shear strains at the ends of the overlap were higher than the bondline of one of the independent hard-type adhesives. In the soft-type adhesive joint, the maximum shear and peel strains were the highest in all specimens. These results suggested that the hardtype adhesive restricted the strain of the adhesive layer. However, the strain distribution of the adhesive layer did not have a direct relationship with the joint strength.

\subsubsection{Strain distribution of the adherend}

Fig. 15 shows contour maps of the shear strain distribution of the adherend. The strain of the right-side adherend was relatively smaller compared to that of the leftside adherend. In focusing on the strain distribution of the

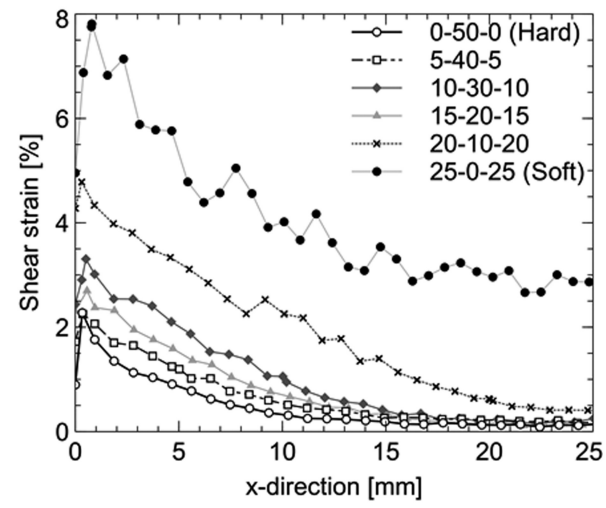

Fig. 13 Each shear strain distribution in the middle of the adhesive layer

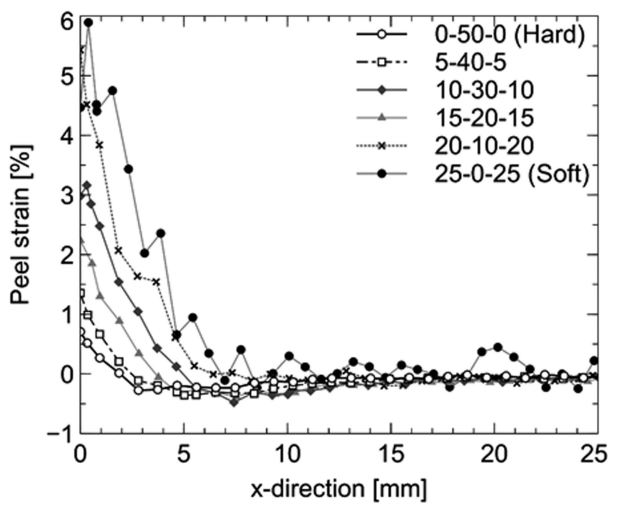

Fig. 14 Each peel strain distribution in the middle of the adhesive layer 


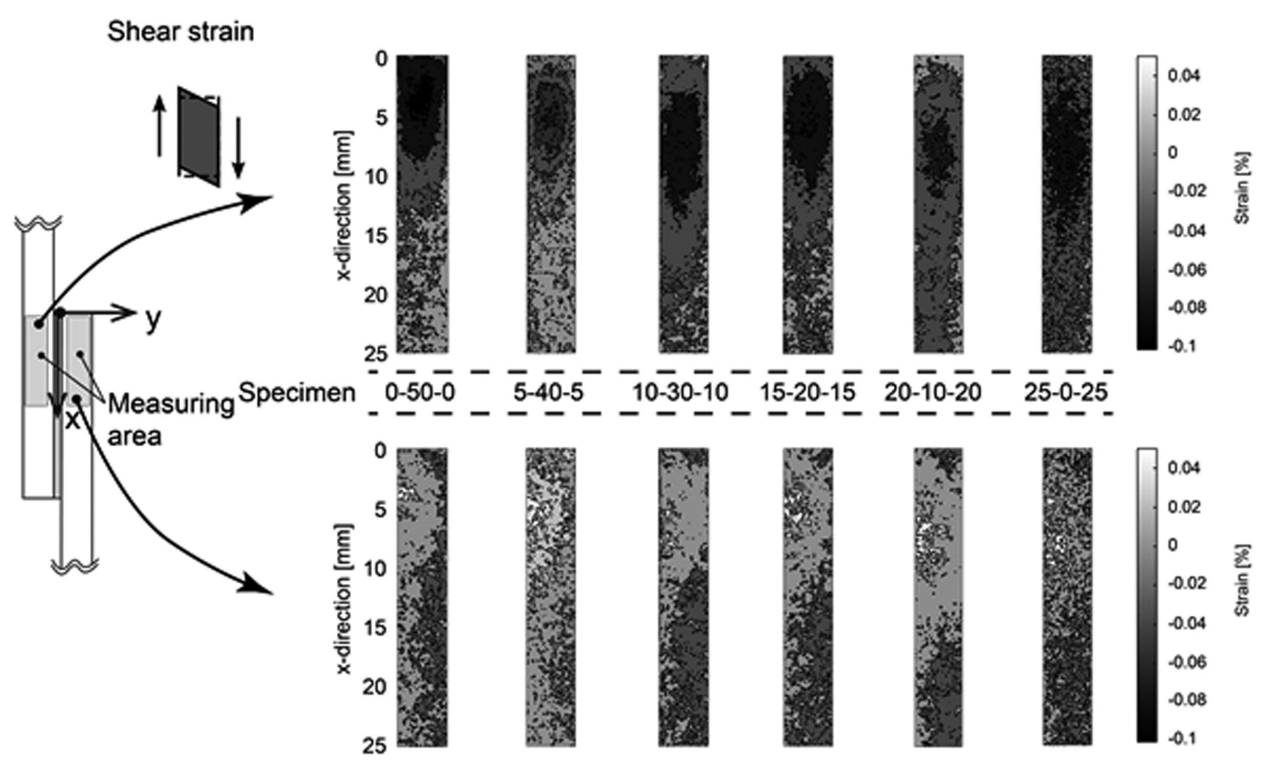

Fig. 15 Shear strain fields of the adherend of each specimen

left-side adherend, the longer was the soft-type adhesive, the more the shear stress concentration point moved to the overlap center. The stress concentration area was spread over a wide area.

Fig. 16 shows contour maps of the normal strain distribution of the adherend. As with the shear strain distribution, the longer the soft-type adhesive, the more the normal strain concentration point moved to the overlap center. Additionally, the stress concentration area was spread over a wide area. The difference of normal strain between each specimen was more prominent than that for the shear strain. These results indicated that the MAJ adherend at the overlap center was bearing the load. It could be inferred that the MAJ adhesive layer at the overlap center was likewise bearing the load.

\subsection{Stress distribution in the bondline}

Fig. 17 shows the shear stress distribution at the middle of the adhesive layer for each specimen. Fig. 18 shows the peel stress distribution along the middle of the adhesive layer for each specimen. There were two stress concentration points: one was near the bondline ends; the other separated the points of different mixing ratio adhesives. The stress near the bondline ends was the maximum for the soft-type adhesive. The stress at the separation point between the different adhesives was also

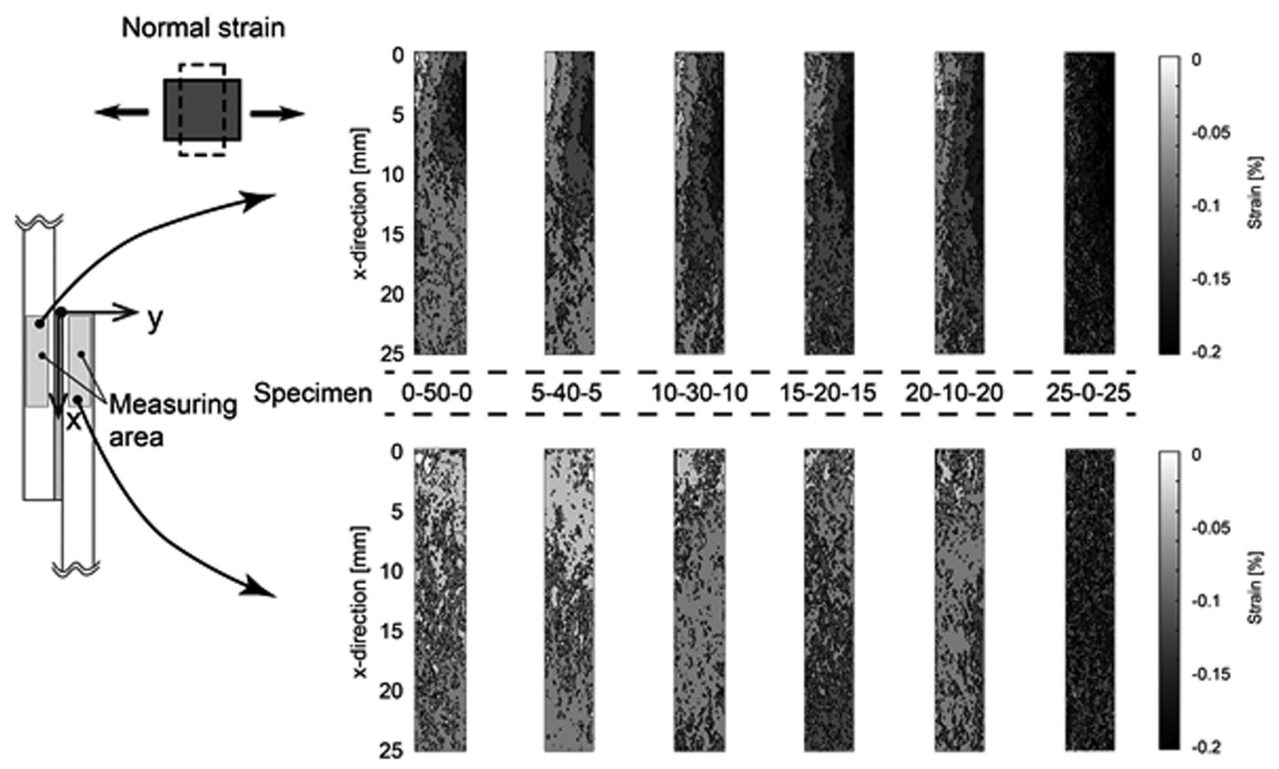

Fig. 16 Normal strain fields of the adherend of each specimen 


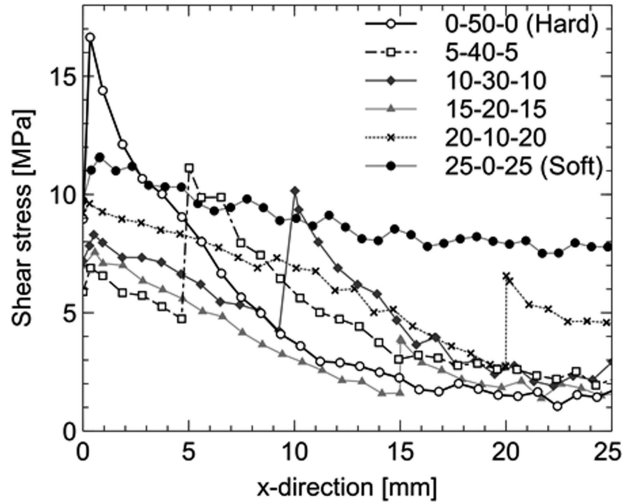

Fig. 17 Each shear stress distribution in the middle of the adhesive layer

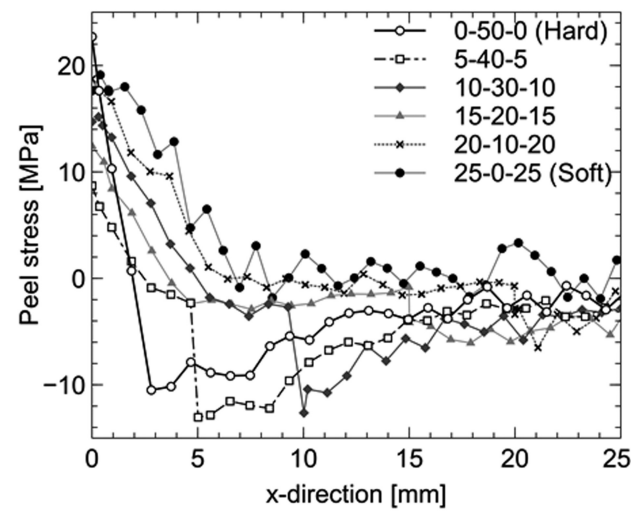

Fig. 18 Each peel stress distribution in the middle of the adhesive layer

the maximum for the hard-type adhesive.

Fig. 19(a) shows the stress values of the adhesive layer ends. At the end of the bondline, the shear and peel stress value of specimen 0-50-0 (independent hard-type adhesive) is the highest of all specimens. For the other specimens, at the end of bondline, the shear stress decreased with the length increase of the hard-type adhesive bondline except for specimen 15-20-15. However, the stress value of specimen 15-20-15 at the bondline end is lower than for the other specimens. We concluded that the flow of hardtype adhesive may have caused the moving mixture ratio distribution of specimen 15-20-15. As a result, the stress was smaller than expected.

Fig. 19(b) shows the stress value at a separate point of the adhesive layer in the MAJ specimens. The compressive stress was generated at separate points. The compressive stresses increased with an increase in the hard adhesive bondline length. Fig. 20 shows the von Mises equivalent stress distribution in the middle of the adhesive layer. In Fig. 21(a), the von Mises equivalent stress values at the end of the adhesive layers is shown. Fig. 21(b) presents the von Mises equivalent stress values at separate points of the

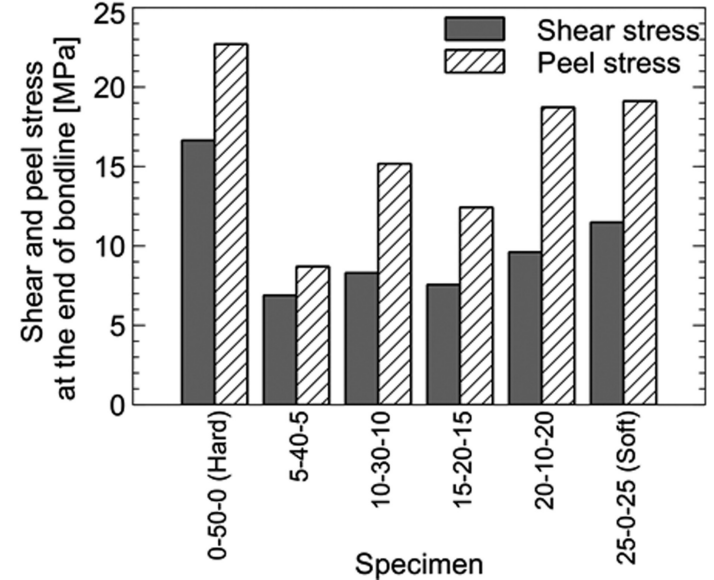

(a)

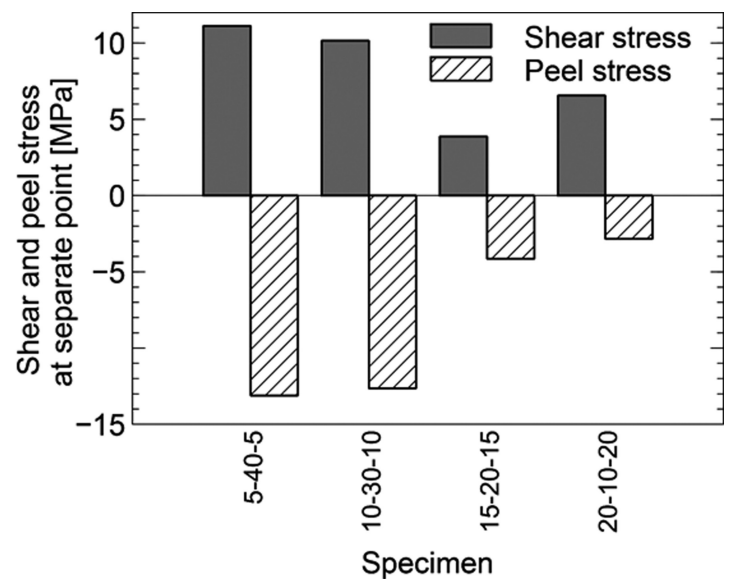

(b)

Fig. 19 (a) Stress values of the adhesive layer end, (b) Stress value at separate points of the adhesive layer in MAJ specimens

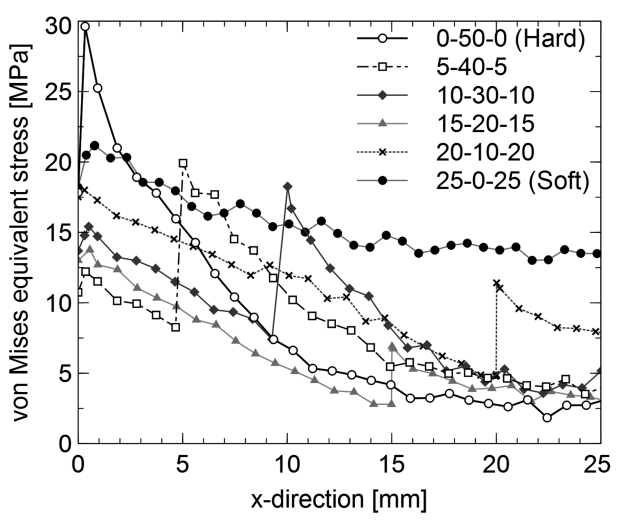

Fig. 20 Each von Mises equivalent stress distribution in the middle of the adhesive layer

adhesives. The von Mises equivalent stress distribution has a large stress concentration at the end of the adhesive layer when only the hard adhesive layer is independently used. Additionally, it is evident that the MAJ soft-type adhesive layer can reduce the von Mises equivalent stress at the adhesive layer end. 


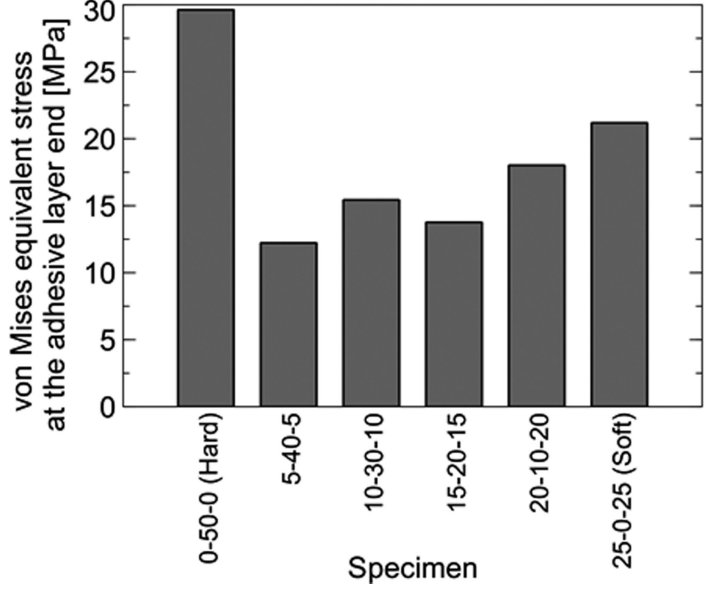

(a)

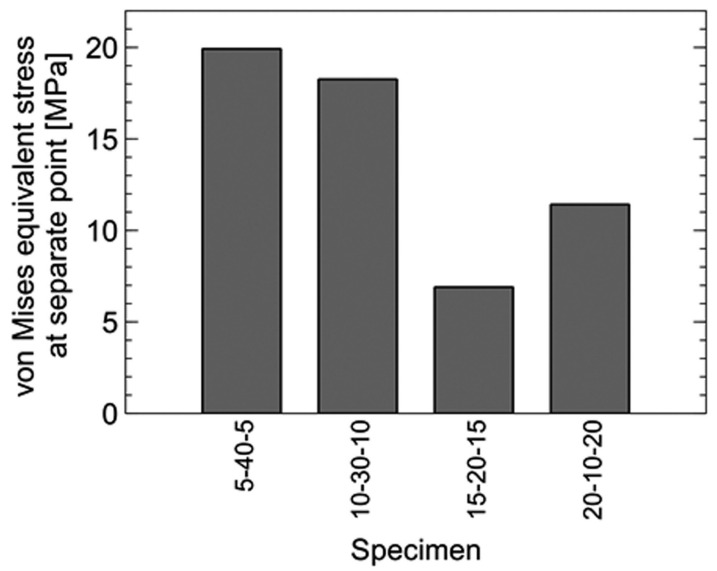

(b)

Fig. 21 (a) von Mises equivalent stress values at the adhesive layer end, (b) von Mises equivalent stress values at separate points

\section{Conclusion}

This article described strain and stress distributions of mixed adhesive joints with various kinds of applied patterns under a static load. Mixed adhesive joints were manufactured by a special application machine using second-generation acrylic adhesives. Strain distributions of mixed adhesive joints were measured using a digital image correlation method. The stress distribution was calculated using the strain distribution by the secant modulus. The results of this study are summarized as follows:

1) The single hard-type adhesive specimen had a low strain in the adhesive layer. In contrast, the adhesive layers of the mixed adhesive joints had relatively higher strain concentrations at the end of the bondline.

2) From the results of the adherend strain distributions, when the soft-type adhesive was used at end of the adhesive layer, the transition of the stress concentration point and the expansion of the high strain region were observed. This result indicated that the adherend of the overlap center was bearing a load, and it could be inferred that the adhesive layer of overlap center was likewise bearing a load.

3) From the shear stress distributions, the maximum shear stress value of the single hard-type adhesive specimen was the highest of all specimens. The MAJ shear stress distributions were lower than those of the single hard-type specimen. Similarly, the MAJ peel stress distributions were lower than that for the single hardtype specimen.

\section{Acknowledgment}

The authors would like to acknowledge the contributions of equipment and technical support provided by Musashi Engineering Co., Ltd.

\section{References}

1) R. D., Adams, J. Comyn, W. C. Wake, "Structural Adhesive Joints in Engineering 2nd ed.”, Chapman \& Hall, p. 1 (1997).

2) A. J. Kinloch, "Adhesion and Adhesives: Science and Technology", Chapman \& Hall, London, p. 1 (1987).

3) L. F. M. da Silva, A. Oechsner, R. D. Adams, "Handbook of Adhesion Technology", Springer, p. 2 (2011).

4) L. J. Hart-smith, NASA CR-112237 (1973).

5) C. Raphael, Appl. Polym. Symp., 3, 99 (1966).

6) R. Breto, A. Chiminelli, E. Duvivier, M. Lizaranzu, M. A. Jiménez, J. Adhes., 91, 920 (2015).

7) S. Kawasaki, G. Nakajima, K. Haraga, C. Sato, J. Adhes., 92, 517, (2016).

8) O. Volkersen, Luftfahrtforschung, 15, 41 (1938).

9) R. D. Adams, J. A. Harris, Int. J. Adhes. Adhes., 7, 69 (1987).

10) L. J. Hart-Smith, NASA CR-112235 (1973).

11) I. Pires, L. Quintino, J. F. Durodola, A. Beevers, Int. J. Adhes. Adhes., 23, 215 (2003).

12) M. D. Fitton, J. G. Broughton, Int. J. Adhes. Adhes., 25, 329 (2005).

13) W. D. James, Experimental Mechanics, 19, 349 (1979).

14) D. Post, Experimental Mechanics, 23, 203 (1983).

15) M.Y. Tsai, Composite Structures, 32, 123 (1995).

16) T. K. Matthew, L. A. Jonghee, S. Kobayashi, Optics and Lasers in Engineering, 40, 231 (2003).

17) M. A. Sutton, W. J. Wolaters, W. H. Peters, W. F. Ranson, S. R. McNeill, Computer Vision, 133 (1983).

18) Z. Sun, J. S. Lyons, S. R. McNeill, Optics and Lasers in Engineering, 27, 409 (1997).

19) R. Haghani, M. Al-Emrani, R. Kliger, Journal of Reinforced Plastics and Composites, 29, 972 (2010).

20) M. Kashfuddoja, M. Ramji, Journal of Composite Materials, 49, 2015, (2015).

21) S. Murakami, Y. Sekiguchi, C. Sato, E. Yokoi, T. Furusawa, Int. J. Adhes. Adhes., 67, 86 (2016)

22) Ncorr 2d-dic software, <http://www.ncorr.com>. 


\title{
＜研究論文 >
}

\section{第二世代アクリル系接着剂を用いて製作した 接着層塗り分け継手のひずみ及び応力分布の評価}

\author{
川崎 翔大**関口悠**・中島 剛介***, \\ 原賀 康介 $* * * *$ - 佐藤 千明 $* *$
}

\begin{abstract}
要
旨

接着接合は他の接合方法にない多くの利点, 例えば軽量化, 異種材料間接合が可能, 応力集中の緩和が可 能などの特徵を持ち, 自動車や航空機などの大荷重が加わる機械にも頻繁に適用されつつある。しかし, 接 着層の端部には応力集中が生じやすく, 継手強度を相対的に低減している。従来からある応力緩和手法とし ては, 継手の幾何学的形状の変形による手法が有り, この手法は強度の向上に有効であるが, 自動化や低コ ス卜化が難しい。被着体の変形を伴わない手法として, 接着層に弾性率の異なる接着剂を複数用いる手法が 提案されているが，実験的にこの応力分布を調べた研究はほとんどない。

本論文では，接着層の端部と中央部を異なる接着剤で塗り分けた試験片を作製し，その引張試験を行った。 この時, デジタル画像相関法により接着層㧍よび被着体のひずみ分布を測定し, さらにこの応力分布を計算 した。この結果，接着層両端部の軟質接着剂層が長くなるほど応力集中が緩和することを確認した。
\end{abstract}

* 東京工業大学 総合理工学研究科 メカノマイクロ工学専攻 神奈川県横浜市緑区長津田町 4259-R2-31％ 226-8503

**東京工業大学 科学技術創成研究院

神奈川県横浜市緑区長津田町 4259-G2-20 † 226-8503

***デンカ(株) 渋川工場

群馬県渋川市中村 1135 † 377-8520

*****(株)原賀接着技術コンサルタント

兵庫県芦屋市緑町 1-9-301 † 659-0042

(原稿受付日：平成 29 年 3 月 3 日) 